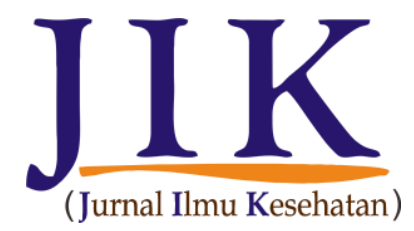

JIK (Jurnal Ilmu Kesehatan)

Online ISSN: 2597-8594

Print ISSN: 2580-930X

Jurnal homepage: https://jik.stikesalifah.ac.id

\title{
Pengaruh KIE Terhadap Tingkat Pengetahuan Pasangan Usia Subur Dalam Pemakaian Alat Kontrasepsi Jangka Panjang
}

\author{
Dewi Fransisca ${ }^{1}$, Melia Pebrina ${ }^{2}$, \\ ${ }^{1,2}$ Program Studi D3 Kebidanan, STIKes Syedza Saintika, Padang, Indonesia \\ Jl. Prof. Dr. Hamka No. 228 Air Tawar Timur Kecamatan Padang Utara, 25132 \\ Email: ${ }^{1}$ alyanisaulfaiha@gmail.com, ${ }^{2}$ meliapebrina88@gmail.com
}

\begin{abstract}
Abstrak
Metode kontrasepsi jangka panjang (MKJP) merupakan salah satu bentuk kontrasepsi yang dipakai dalam jangka waktu lama, efektif dan efisien untuk menjarangkan kelahiran lebih dari 3 tahun. Beberapa faktor penghambat pencapaian akseptor MKJP salah satunya adalah kurangnya pengetahuan PUS mengenai alat kontrasepsi sehingga masyarakat enggan menggunakan MKJP. Tujuan penelitian ini adalah mempelajari pengaruh penyuluhan terhadap tingkat pengetahuan PUS dalam pemakaian metode kontrasepsi jangka panjang (MKJP). Jenis penelitian ini Quasy Exsperiment dengan pendekatan One Group Pretest Posttest Design. Penelitian ini dilakukan di wilayah kerja puskesmas padang pasir kota Padang Sumatera Barat tahun 2019. Teknik pengambilan sampel secara Purposive Sampling. Berdasarkan rumus yang digunakan, sampel pada penelitian ini sebanyak 22 orang. rata-rata tingkat pengetahuan pasangan usia subur (PUS) sebelum diberikan KIE tentang MKJP adalah mean 59,09 dan SD 12,58. Rata-rata tingkat pengetahuan PUS sesudah diberikan KIE adalah mean 81,27 dan SD 7,94. Hasil uji T dependen didapatkan nilai $\rho=0,000$, dapat disimpulkan ada pengaruh komunikasi, informasi dan edukasi terhadap tingkat pengetahuan pasangan usia subur.
\end{abstract}

Kata Kunci: Komunikasi informasi dan Edukasi, Tingkat Pengetahuan, Metode Kontrasepsi Jangka Panjang

\section{The Influence of CIE on The Level of Knowledge of Couples of Childbearing Age in Using Long-Term Contraception}

\begin{abstract}
Long-term contraceptive method (MKJP) is one form of contraception that is used for a long time, effective and efficient for spacing births of more than three years. Some of the factors that inhibit the achievement of MKJP acceptors are the lack of knowledge of fertile age couples regarding contraception that people are reluctant to use MKJP. The purpose of this study was to study the effect of counseling on the level of knowledge of couples of reproductive age in the use of long-term contraceptive methods (MKJP). This type of research is QuasyExsperiment with the One Group PretestPosttest Design approach. This research was carried out in the working area of the desert health center, Padang City, West Sumatra, in 2019. The sampling technique was purposive sampling. Based on the formula used, the sample in this study was 22 people. The average level of knowledge of couples of childbearing age before being given IEC about MKJP is the mean of 59.09 and SD 12.58. The average level of knowledge of couples of childbearing age after being given IEC is the mean of 81.27 and SD 7.94. The results of the dependent t-test are $\rho=0,000$; it can have concluded that there is an influence of communication, information, and education on the level of knowledge of couples of childbearing age.
\end{abstract}

Keywords: Information Communication and Education, Level of Knowledge, Long-Term Contraceptive Methods 


\section{PENDAHULUAN}

Dalam rangka pembangunan jangka menengah nasional ( RPJMN ) tahun 20092014, bahwa dalam rangka mempercepat pengendalian fertilitas dilakukan melalui penggunaan kontrasepsi. Program Keluarga Berencana Nasional lebih diarahkan kepada pemakaian metode kontrasepsi jangka panjang (MKJP). MKJP adalah kontrasepsi yang dapat dipakai dalam jangka waktu lama, efektif dan efisien untuk menjarangkan kelahiran lebih dari 3 tahun. Jenis metode yang termasuk dalam kelompok ini adalah metode kontrasepsi mantap (MOW/MOP), intra uterine device (IUD) dan implant (B. K. dan K. B. Nasional, 2014).

Laporan Renstra 2015-2019 menunjukkan bahwa target perbandingan capain peserta KB Aktif MKJP adalah tahun 2015 sebanyak 20,5\%, 2016 sebanyak $21,1 \%$, tahun 2017 sebanyak 21,7\%, tahun 2018 sebanyak 22,3\% dan tahun 2019 sebanyak 23,5\% (BKKBN, 2015). Pencapaian peserta KB baru MKJP tahun 2016 di Provinsi Sumatera Barat adalah 23,03 (116,90\%) dari $19,7 \%$ dari target yang telah ditetapkan. Dan pencapaian peserta KB Aktif MKJP sebanyak $30,06(130,13 \%)$ dari $23,1 \%$ target yang telah ditentukan (B. K. dan K. B. S. B. Nasional, 2017).

Sejalan dengan hasil Data Riset Kesehatan Dasar (RISKESDAS) menunjukkan bahwa pada tahun 2013 wanita usia 15-49 tahun dengan status kawin sebesar $59,7 \%$. PUS menggunakan KB modern (Implan, MOW, MOP, IUD, Kondom, Suntik dan Pil), dan 0,4\% menggunakan KB tradisional (MAL, Kalender dan Senggama terputus). Selain itu sebanyak 24,7\% PUS pernah menggunakan KB dan $15,5 \%$ tidak menggunakan KB. Metode kontrasepsi yang paling banyak digunakan oleh peserta KB baru ialah suntik sebanyak 48,56\% (RI, 2014).

Menurut Laporan Kinerja BKKBN tahun 2015 faktor penghambat pencapaian akseptor MKJP diantaranya akses bagi PUS untuk mendapatkan pelayanan kontrasepsi jangka panjang sangat terbatas, masalah teknis seperti dokter dan bidan yang ditempatkan di daerah belum memiliki keahlian dalam pemasangan alat kontrasepsi MKJP, dan kurangnya pengetahuan Pasangan Usia Subur
(PUS) mengenai alat kontrasepsi sehingga masyarakat enggan menggunakan MKJP (B. K. dan K. B. Nasional, 2015).

Berdasarkan penelitian yang dilakukan oleh (Ulle, AJ. Utami, NW, 2017) dengan judul "Pengaruh Penyuluhan Kesehatan Tentang KB Terhadap Motivasi Dalam Memilih Alat Kontrasepsi Di Desa Bera Dolu Sumba Barat Nusa Tenggara Timur (NTT)" didapatkan hasil penelitian sebanyak $63,6 \%$ responden memiliki motivasi yang lemah dalam memilih alat kontrasepsi sebelum penyuluhan. Setelah dilakukan penyuluhan sebanyak $81,8 \%$ responden memiliki motivasi yang kuat dalam memilih alat kontrasepsi. Didapatkan nilai $\rho$ yaitu 0,001 dengan nilai $\alpha$ $(0,05)$, dapat disimpulkan terdapat pengaruh penyuluhan kesehatan tentang Keluarga Berencana terhadap memilih alat kontrasepsi.

Menurut (Ulle, AJ. Utami, NW, 2017). Komunikasi, Informasi, dan Edukasi (KIE) yang efektif kepada calon akseptor, dapat memberikan asuhan kesehatan, dan advokasi kepada calon akseptor terhadap ketepatan menggunakan alat kontrasepsi. Tujuan penelitian ini adalah mempelajari pengaruh penyuluhan terhadap tingkat pengetahuan PUS dalam pemakaian metode kontrasepsi jangka panjang (MKJP).

Adapun tujuan penelitian ini adalah mempelajari pengaruh komunikasi informasi dan edukasi terhadap tingkat pengetahuan PUS dalam pemakaian metode kontrasepsi jangka panjang (MKJP).

\section{METODE PENELITIAN}

Jenis penelitian ini adalah Quasy experiment dengan pendekatan rancangan one group pretest posttest yaitu pengelompokan anggota-anggota kelompok eksperimen. Penelitian ini menguji perubahan-perubahan yang terjadi pada kelompok setelah adanya eksperimen (perlakuan).

Penelitian ini dilakukan di Wilayah Kerja Puskesmas Padang Pasir Kota Padang. Waktu penelitian dilaksanakan dari bulan Mai - September 2019. Populasi penelitian ini adalah seluruh pasangan usia subur (PUS) yang tidak menggunakan kontrasepsi di wilayah kerja Puskesmas Padang Pasir. Sampel yang diambil adalah yang memenuhi kriteria inklusi dan eksklusi penelitian. 
Kriteria Inklusi: Wanita berstatus menikah, Seluruh pasangan usia subur yang tidak menggunakan kontrasepsi, Bisa baca tulis, Bersedia menjadi responden dan berada di tempat. Jumlah sampel pada penelitian ini sebanyak 22 orang yang didapatkan melalui rumus sampel.

Variabel Independen yaitu Komunikasi Informasi dan Edukasi dan Variabel Dependen yaitu Tingkat Pengetahuan. Definisi dan klasifikasi variabel yang diteliti yaitu 1). Komunikasi Informasi dan Edukasi adalah suatu metode konseling yang dilakukan dalam pencapaian akseptor keluarga berencana. 2). Tingkat Pengetahuan adalah segala sesuatu yang diketahui pasangan usia subur dalam pemakaian alat kontrasepsi jangka panjang. Alat ukur berupa kuesioner dan skala ukur rasio.

Pengumpulan data dilakukan dengan angket menggunakan kuisioner kepada responden yang ada di Kelurahan Rimbo Kaluang Wilayah Kerja Puskesmas Padang Pasir yang sesuai dengan kriteria inklusi. Tahap awal dilakukan penilaian terhadap tingkat pengetahuan pasangan usia subur melalui kuesioner (pretest), kemudian dilakukan konseling mengenai alat kontrasepsi jangka panjang. Setelah konseling dilakukan dinilai kembali tingkat pengetahuan responden melalui kuesioner (posttest).

Analisis data menggunakan program komputer SPSS, uji normalitas data menggunakan shapiro-wilk, untuk mengetahui pengaruh penyuluhan terhadap tingkat pengetahuan PUS menggunakan uji TDependent.

\section{HASIL DAN PEMBAHASAN}

Tabel 1. Rata-rata tingkat pengetahuan pasangan usia subur (PUS) sebelum diberikan komunikasi, informasi dan edukasi dalam pemakaian metode kontrasepsi jangka panjang

\begin{tabular}{lllll}
\hline Variabel & $\mathrm{N}$ & Mean & SD & $\begin{array}{c}\text { Max- } \\
\text { Min }\end{array}$ \\
\hline Pretest & 22 & 59,09 & 12,585 & $20-9$ \\
\hline
\end{tabular}

Berdasarkan tabel 1 diketahui rata-rata tingkat pengetahuan Pasangan Usia Subur dalam pemakaian metode kontrasepsi jangka panjang sebelum diberikan komunikasi, informasi dan edukasi (KIE) yaitu 59,09 dengan standar deviasi (SD) yaitu 12,58. Tingkat pengetahuan maximum responden 20 dan tingkat pengetahuan minimum 9 di kelurahan rimbo kaluang wilayah kerja puskesmas padang pasir kota Padang.

Berdasarkan hasil penelitian yang dilakukan, tingkat pengetahuan PUS dalam pemakaian metode kontrasepsi jangka panjang sebelum diberikan komunikasi, informasi, dan edukasi (KIE) yaitu 59,09, dengan standar deviasi (SD) yaitu 12,585. Tingkat pengetahuan maximum responden 20 dan tingkat pengetahuan minimum responden 9 di Kelurahan Rimbo Kaluang Wilayah Kerja Puskesmas Padang Pasir Kota Padang.

Hasil penelitian ini sama dengan penelitian yang dilakukan oleh (Ulle, AJ. Utami, NW, 2017) tentang pengaruh penyuluhan kesehatan tentang KB terhadap tingkat motvasi dalam memilih alat kontrasepsi di Desa Bera Dolu Sumba Barat Nusa Tenggara Timur ( NTT ), ditemukan rata-rata pengetahuan pasangan usia subur ( PUS ) sebelum diberikan penyuluhan yaitu 63,6. Selain itu penelitian lain yang mendukung adalah penelitian yang dilakukan oleh (Rahimah, 2012) dengan judul efektifitas Komunikasi, Informasi Dan Edukasi (KIE) dengan metode ceramah dan media leaflet terhadap pengambilan keputusan PUS dalam memilih alat kontrasepsi di wilayah kerja Puskesmas Langsa Lama Kota Langsa tahun 2012, ditemukan rata-rata tingkat pengetahuan sebelum diberikan sebelum diberikan intervensi dengan media leaflet adalah 35,47.

Tabel 2. Rata-rata tingkat pengetahuan pasangan usia subur (PUS) sesudah diberikan komunikasi, informasi dan edukasi dalam pemakaian metode kontrasepsi jangka panjang

Variabel N Mean SD $\begin{gathered}\text { Max } \\ \text { Min }\end{gathered}$


Berdasarkan tabel 2. diketahui ratarata tingkat pengetahuan PUS dalam pemakaian metode kontrasepsi jangka panjang sesudah diberikan komunikasi, informasi dan edukasi (KIE) yaitu 81,27 dengan standar deviasi (SD) yaitu 7,94. Tingkat pengetahuan maximum responden 24 dan tingkat pengetahuan minimum responden 16 di kelurahan rimbo kaluang wilayah kerja puskesmas padang pasir kota Padang.

Hasil penelitian ini sejalan dengan penelitian yang dilakukan oleh (Ulle, AJ. Utami, NW, 2017) tentang pengaruh penyuluhan kesehatan tentang KB terhadap tingkat motvasi dalam memilih alat kontrasepsi di Desa Bera Dolu Sumba Barat Nusa Tenggara Timur (NTT), ditemukan ratarata pengetahuan pasangan usia subur (PUS) sesudah diberikan penyuluhan yaitu 81,8 . Selain itu penelitian lain yang mendukung penelitian ini juga dilakukan oleh (Rahimah, 2012) dengan judul efektifitas Komunikasi, Informasi dan Edukasi (KIE) dengan metode ceramah dan media leaflet terhadap pengambilan keputusan PUS dalam memilih alat kontrasepsi di wilayah kerja Puskesmas Langsa Lama Kota Langsa tahun 2012, ditemukan rata-rata tingkat pengetahuan setelah diberikan intervensi dengan media leaflet adalah 67,38.

Pengetahuan dan sikap berkaitan erat dengan peningkatan sumber daya manusia karena semakin tinggi pengetahuan dan sikap seseorang maka semakin tinggi pula kesadaran dalam suatu keluarga khususnya ibu PUS dalam memakai kontrasepsi. Hal ini sesuai dengan teori (Notoatmojo, 2016) yang menyatakan bahwa pengetahuan merupakan domain yang sangat penting untuk terbentuknya tindakan seseorang (over behavior).

Tabel 3. Pengaruh Komunikasi, Informasi dan Edukasi (KIE) terhadap Tingkat Pengetahuan PUS dalam pemakaian metode kontrasepsi jangka panjang

\begin{tabular}{ccccccc}
\hline Variabel & $\mathrm{N}$ & Mean & SD & Min & Max & $\rho$ \\
\hline Pretest & 22 & 59,09 & 12,585 & 9 & 20 & \\
Postest & 22 & 81,27 & 7,941 & 16 & 24 & 0,0 \\
\hline
\end{tabular}

Berdasarkan tabel 3. diketahui bahwa terdapat pengaruh komunikasi, informasi dan edukasi (KIE) terhadap tingkat pengetahuan pasangan usia subur (PUS) dalam pemakaian metode kontrasepsi jangka panjang. Di dapatkan hasil uji T Dependen nilai $\rho=0,000$.

Hasil penelitian ini, ada peningkatan tingkat pengetahuan minimum responden dari 9 menjadi 16 setelah diberikan komunikasi, informasi, dan edukasi (KIE) dan tingkat pengetahuan maksimum responden dari 20 menjadi 24 setelah dilakukan komunikasi, informasi, dan edukasi (KIE). Hal ini menandakan bahwa kegiatan komunikasi, informasi, dan edukasi (KIE) yang dilakukan efektif karena terjadi peningkatan pengetahuan dan pemahaman PUS.

Hasil penelitian ini sama dengan penelitian yang dilakukan oleh (Ulle, AJ. Utami, NW, 2017) tentang pengaruh penyuluhan kesehatan tentang KB terhadap tingkat motivasi dalam memilih alat kontrasepsi di Desa Bera Dolu Sumba Barat Nusa Tenggara Timur (NTT), ditemukan nilai signifikansi yaitu 0,001 dengan nilai $\alpha(0,05)$, dapat disimpulkan terdapat pengaruh penyuluhan kesehatan tentang keluarga berencana terhadap motivasi dalam memilih alat kontrasepsi di Desa Bera Dolu Sumba Barat NTT. Selain itu penelitian lain yang mendukung penelitian ini juga dilakukan oleh (Rahimah, 2012) dengan judul efektifitas Komunikasi, Informasi Dan Edukasi (KIE) dengan metode ceramah dan media leaflet terhadap pengambilan keputusan PUS dalam memilih alat kontrasepsi di wilayah kerja Puskesmas Langsa Lama Kota Langsa tahun 2012 , ditemukan $p$ value $=0,001$. Hal ini berarti bahwa secara statistik dapat diketahui bahwa ada pengaruh pemberian Komunikasi, Informasi dan Edukasi (KIE) terhadap pengambilan keputusan PUS dalam memilih alat kontrasepsi dengan metode ceramah dan leaflet dimana nilai $p<0,05(p=0,001)$.

Komunikasi Informasi dan Edukasi (KIE) adalah suatu proses penyampaian pesan, informasi yang diberikan kepada masyarakat tentang program KB baik menggunakan media seperti: radio, $\mathrm{TV}$, film, mobil unit penerangan, penerbitan, kegiatan promosi, pameran dengan tujuan utama adalah untuk memecahkan masalah dalam lingkungan 
masyarakat dan meningkatkan program $\mathrm{KB}$ atau sebagai penunjang tercapainya program KB (Sulistyawati, 2011). Kurangnya KIE (Komunikasi Informasi Edukasi) oleh tenaga kesehatan salah satu faktor penghambat masyarakat untuk memperoleh informasi yang benar mengenai $\mathrm{KB}$, sehingga menyebabkan partisipasi masyarakat dalam kegiatan $\mathrm{KB}$ berkurang. KIE hendaknya dilakukan secara rutin untuk meningkatkan pengetahuan, sikap, dan praktik KB serta partisipasi masyarakat dalam ber KB sehingga terdapat penambahan peserta baru dan membina kelestarian peserta KB (B. K. dan K. B. Nasional, 2014), (Suharti, 2016). Menurut Dewi dan Notobroto dalam penelitiannya mengungkapkan Faktor-faktor yang menyebabkan PUS tidak menjadi peserta $\mathrm{KB}$ adalah pelayanan KB yang masih kurang berkualitas, keterbatasan alat kontrasepsi, penyampaian konseling maupun KIE (komunikasi, informasi, dan edukasi) belum dilaksanakan dengan baik, dan hambatan budaya (Dewi, PHC, Notobroto, 2014).

Pada penelitian ini ada pengaruh komunikasi informasi dan edukasi (KIE) terhadap tingkat pengetahuan pasangan usia subur. Hal ini menunjukkan bahwasanya KIE yang dilakukan sangat berpengaruh dan berperan penting terhadap peningkatan pengetahuan calon akseptor $\mathrm{KB}$, sehingga akseptor KB mengetahui jenis kontrasepsi yang aman dan tepat untuk digunakan. Selain itu KIE juga berperan penting terhadap peningkatan pencapaian akseptor KB jangka panjang. Hal ini sesuai dengan teori yang menyatakan tujuan utama dari KIE adalah untuk memecahkan masalah dalam lingkungan masyarakat dan meningkatkan program KB atau sebagai penunjang tercapainya program KB. Jenis KIE yang digunakan pada penelitian ini adalah konseling atau penyuluhan.

\section{SIMPULAN}

Kesimpulan dari penelitian ini adalah ada pengaruh komunikasi informasi dan edukasi terhadap tingkat pengetahuan pasangan usia subur (PUS) dalam pemakaian metode kontrasepsi jangka panjang. Hal ini terlihat melalui adanya perubahan tingkat pengetahuan antara sebelum dengan sesudah pemberian konseling. Perubahan tersebut berupa peningkatan pengetahuan pasangan usia subur mengenai metode kontrasepsi jangka panjang.

Bagi petugas kesehatan agar dapat memberikan informasi kesehatan khususnya dalam hal ini mengenai keluarga berencana guna meningkatkan pengetahuan bagi pasangan usia subur yang akan memilih dan menggunakan kontrasepsi, serta sosialisasi tentang program $\mathrm{KB}$ dan pemberian paket edukasi tentang alat kontrasepsi.

\section{UCAPAN TERIMAKASIH}

Ucapan terima kasih penulis sampaikan kepada DRPM RISTEKDIKTI yang telah membantu pendanaan penelitian ini sehingga penelitian ini barjalan lancar dan sesuai tujuan. Dinas Kesehatan Kota Padang dalam hal ini telah memberi izin kepada penulis untuk dapat melaksanakan penelitian di Puskesmas Padang Pasir. Puskesmas padang pasir yang telah memfasilitasi penelitian ini berupa pemberian data-data akseptor KB dan jumlah pasangan usia subur di wilayah kerja Puskesmas Padang Pasir. Ucapan terima kasih kepada kader yang telah membantu dan menemani pelaksanaan penelitian. Dan tak lupa ucapan terima kasih penulis sampaikan kepada pasangan usia subur yang berada di wilayah kerja puskesmas padang pasir telah bersedia menjadi responden pada penelitian ini.

\section{DAFTAR PUSTAKA}

Dewi, PHC, Notobroto, H. (2014). Rendahnya Keikutsertaan Pengguna Metode Kontrasepsi Jangka Panjang Pada Pasangan Usia Subur. Jurnal Biometrika Dan Kependudukan, Volume 3, (Nomor 1), hlm 66-72.

Nasional, B. K. dan K. B. (2014). Informasi Data Program KB Nasional. Retrieved from http://www.bkkbn.go.id

Nasional, B. K. dan K. B. (2015). Laporan Kinerja Instansi Pemerintah BKKBN. Retrieved from http://www.bkkbn.go.id

Nasional, B. K. dan K. B. S. B. (2017). Review Program KKBPK tahun 2017 Provinsi Sumatera Barat. Retrieved from http://www.bkkbn.go.id

Notoatmojo, S. (2016). Kesehatan 
Masyarakat. Jakarta: Rineka Cipta.

Rahimah. (2012). Efektivitas Komunikasi, Informasi Dan Edukasi (KIE) Dengan Metode Ceramah Dan Media Leaflet Terhadap Pengambilan Keputusan PUS Dalam Memilih Alat Kontrasepsi. Universitas Sumatera Utara.

RI, K. K. (2014). Profil Kesehatan Indonesia Tahun 2013. Retrieved from http://www.depkes.go.id

Suharti, S. (2016). Efektivitas KIE (Komunikasi, Informasi dan Edukasi)
Terhadap Penggunaan KB IUD (INTRA UTERINE DEVICES). Jurnal Ilmiah Kebidanan IMELDA, Volume 2,

Sulistyawati, A. (2011). Pelayanan Keluarga Berencana. Jakarta: Salemba Medika.

Ulle, AJ. Utami, NW, S. (2017). Pengaruh Penyuluhan Kesehatan Tentang KB Terhadap Motivasi Dalam Memilih Alat Kontrasepsi. Nursing News, Volume 2, . 